IRSH 64 (2019), pp. 95-I 24 doi:I0.1017/S002085901900004X

(C) 2019 Internationaal Instituut voor Sociale Geschiedenis. This is an Open Access article, distributed under the terms of the Creative Commons Attribution licence (http://creativecommons.org/licenses/by/4.o/), which permits unrestricted re-use, distribution, and reproduction in any medium, provided the original work is properly cited.

\title{
Between the Plantation and the Port: Racialization and Social Control in Eighteenth-Century Paramaribo
}

\author{
PEPIJN BRANDON \\ International Institute of Social History \\ Cruquiusweg 3I, IOI9 AT Amsterdam, The Netherlands \\ Vrije Universiteit \\ De Boelelaan I I05, I08I HV Amsterdam, The Netherlands \\ E-mail: pepijn.brandon@iisg.nl
}

\begin{abstract}
Starting from an incident in the colonial port city of Paramaribo in the autumn of 1750 in which, according to the Dutch governor Mauricius, many of the proper barriers separating rich and poor, men and women, adults and children, white citizens and black slaves were crossed, this article traces some of the complexities of everyday social control in colonial Suriname. As gateways for the trade in commodities and the movement of people, meeting points for free and unfree labourers, and administrative centres for emerging colonial settlements, early modern port cities became focal points for policing interaction across racial and social boundaries. Much of the literature on the relationship between slavery and race focuses on the plantation as "race-making institution" and the planter class as the immediate progenitors of "racial capitalism". Studies of urban slavery, on the other hand, have emphasized the greater possibilities of social contact between blacks, mestizos, and whites of various social status in the bustling port cities of the Atlantic. This article attempts to understand practices of racialization and control in the port city of Paramaribo not by contrasting the city with its plantation environment, but by underlining the connections between the two social settings that together shaped colonial geography. The article focuses on everyday activities in Paramaribo (dancing, working, drinking, arguing) that reveal the extent of contact between slaves and nonslaves. The imposition of racialized forms of repression that set one group against the other, frequently understood primarily as a means to justify the apparent stasis of the plantation system with its rigid internal divisions, in practice often functioned precisely to fight the pernicious effects of mobility in mixed social contexts.
\end{abstract}




\section{INTRODUCTION ${ }^{\mathrm{I}}$}

On Saturday, 3 October 1750, a joyful sight greeted the Governor General of Suriname, Johan Jacob Mauricius. Along Paramaribo's Waterkant, the quay adorned with tamarind and orange trees stretching out from the square where the governor's mansion was located, most of the ships ran flags and fired their guns "as if it were the birthday of the Prince". ${ }^{2}$ However, the occasion of these festivities greatly annoyed the Dutch governor. For several years, Paramaribo had been the scene of a long feud between Mauricius and sections of the planter class well-entrenched in Suriname's governing council. The conflict can be situated in a wider Atlantic moment of Creole triumphalism in which colonial elites started to challenge the political and economic restrictions imposed by their respective motherlands, and would result in the ousting of Mauricius in April $175 \mathrm{r} .^{3}$ In this context of increasing political tensions, Johanna Catharina Brouwer (born Bedloo), one of the most vocal members of the opposition and widow of Everhard Brouwer, the recently deceased former captain of the citizens' guard and member of the governing council, had organized a provocative ball to celebrate the birthday of her five-year-old daughter. ${ }^{4}$ During the rowdy birthday party, which went on well into the night, fireworks and oranges were thrown at the governor's house, soldiers and slaves broke curfews regulating movement

I. I would like to thank the participants in the two workshops on "Free and Unfree Labor in Atlantic and Indian Port Cities (c.1700-1850)" held at the University of Pittsburgh in May 2016 and May 2017, and the N.W. Posthumus conference at the Radboud University in Nijmegen in June 2017 for their suggestions. Special thanks go to Seymour Drescher, Dienke Hondius, Pernille Røge, Niklas Frykman, and Lex Heerma van Voss, who commented on the paper in detail. I also want to express my gratitude to my students Annette Bosscher, Alida Jones, and Theo Mulder, who worked with me on this source material in the context of a course at the Vrije Universiteit Amsterdam. Their insightful questions and observations were helpful for me while finishing this article, and they also managed to unearth a couple of beautiful details that I integrated into the final version. The research for this article was made possible by an NWO Rubicon grant, project number 446-1 3-007.

2. National Archives, The Hague, Oud Archief Suriname [hereafter, NA-OAS], I.05.10.01, Gouvernementssecretarie, no. 5, "Journaal Mauricius 1748-1750", entry for 3 October 1750.

3. The political conflicts surrounding Mauricius's governorship are described at length in Gerard Willem van der Meiden, Betwist bestuur. Een eeuw strijd om de macht in Suriname I65 I-I753 (Amsterdam, I987). Accounts that focus more on the social aspects can be found in J. Marten W. Schalkwijk, The Colonial State in the Caribbean: Structural Analysis and Changing Elite Networks in Suriname 1650-1920 (The Hague, 2011); and Karwan Fatah-Black, White Lies and Black Markets: Evading Metropolitan Authority in Colonial Suriname, 1650-I800 (Leiden and Boston, MA, 2015). On the wider Atlantic moment of Creole triumphalism, see Bernard Bailyn, Atlantic History: Concept and Contours (Cambridge, MA, 2005), p. I०I; and Jeremy Adelman, Sovereignty and Revolution in the Iberian Atlantic (Princeton, NJ and Oxford, 2006), pp. I46-I47.

4. Biographical background information on Johanna Catharina Brouwer can be found in Fred. Oudschans Dentz, "De fortuinlijke loopbaan in Suriname van den Zweed C.G. Dahlberg”, De West-Indische Gids, 23:I (194I), pp. 269-279. 
in the city at night, and the authorities were taunted and mocked by adults and children. Only at midnight did the bailiff succeed in finally disbanding the riotous birthday party of Brouwer's happy five-year-old. Three days later, the exasperated Mauricius wrote a long report of the incident to the authorities of the Reformed Church and the directors of the Society of Suriname in Amsterdam, in which he warned that "all respect for God and Government has broken down here, how these are being mocked openly, and spat in the face. Yes, how little children and slaves are being taught to cuss at them".'

A long line of social history on medieval and early modern Europe has concentrated on the way in which internal conflict among sections of the ruling classes could open up spaces for wider social explosions, laying bare existing tensions between political and economic elites and subalterns. In this literature, special importance is attached to rites, festivities, and acts of public shaming, such as rough music, as moments in which social norms and barriers were simultaneously revealed and transgressed. ${ }^{6}$ As the reference to the slaves in Mauricius's outcry reminds us, such transgressions were even more dangerous in a plantation colony in which the bedrock of all social relations was slavery. This article takes a thick description of the many social norms invoked and transgressed in the evening of 3 October 1750 as a starting point to examine everyday practices of social control in Paramaribo, the town of five to six thousand inhabitants that stood at the centre of the colonial Suriname's commerce. In particular, it will look at the way in which, in an Atlantic slave port, more familiar and generally applied aspects of enforcing social order - restricting movement, maintaining social distinctions, effecting taboos on interaction - intersected with a process of racialization, by which skin colour itself became a key determinant of one's position in society. Racialization has not been a prominent theme in the study of the

5. Salomon du Plessis (ed.), Recueil van egte stukken en bewyzen ... tegens Mr. Jan Jacob Mauricis etc. 5 vols (s.1., I752), IV, p. 295, Report by Mauricius to the Society of Suriname of 6 October 1750. Italics in the original. The fact that women and children were among the key protagonists drawing Mauricius's ire is important. While this article is about racialization rather than the enforcement of gender differences, in practice the two intertwined in intricate ways. The subsections that follow draw attention to this at several points, but the theme deserves further development. See the contributions by Titas Chakraborty and Melina Teubner in this Special Issue.

6. Classic texts are Natalie Zemon Davis, "The Reasons of Misrule: Youth Groups and Charivaris in Sixteenth-Century France", Past \& Present, 50 (197I), pp. 4I-75; Edward P. Thompson, “Rough Music': Le Charivari Anglais”, Annales. Histoire, Sciences Sociales, 27:2 (1972), pp. 285-3I2; Natalie Zemon Davis, "The Rites of Violence: Religious Riot in Sixteenth-Century France”, Past E Present, 59:2 (1973), pp. 5 I-91. See also the exchange of letters between these two authors in Alexandra Walsham, "Rough Music and Charivari: Letters Between Natalie Zemon Davis and Edward Thompson, 1970-1972”, Past E Present, 235:I (2017), pp. 243-262. 


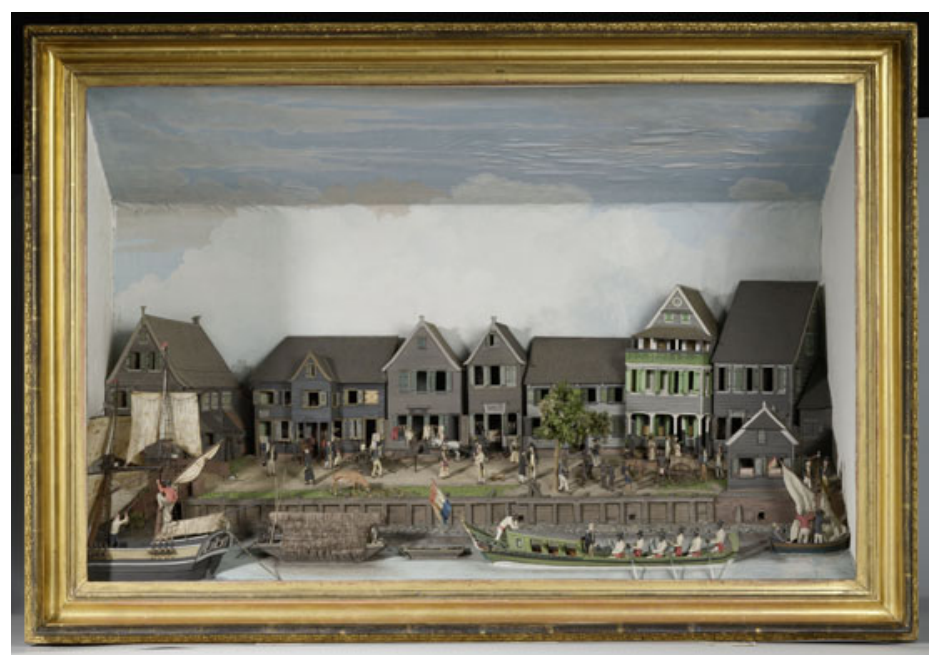

Figure I. Diorama of the Paramaribo Waterfront (Waterkant), Gerrit Schouten, I 820. Rijksmuseum, Amsterdam.

Dutch Atlantic. ${ }^{7}$ This dovetails with more general trends in Dutch historiography, which has often treated the social construction of race as a non-issue. ${ }^{8}$ When historians have discussed race at all, they have done so frequently in a way that treats the emergence of phenotypical differences as key markers of distinction as an almost self-explanatory fact. Starting from places where we can see interaction between different social groups at work - from the squares and the loading docks, the bars and the neighbourhood brawls can help us to look beyond the apparent naturalness of the success of racially segregationist policies pursued by colonial authorities. ${ }^{9}$

7. Typically, a recent volume that summarizes the results of the current wave of interest in Atlantic studies in the Netherlands barely mentions race or racialization, and only marginally discusses slavery. Gert Oostindie and Jessica V. Roitman (eds), Dutch Atlantic Connections, I680-I800: Linking Empires, Bridging Borders (Leiden and Boston, MA, 20I4).

8. Kwame Nimako, Amy Abdou, and Glenn Willemsen, "Chattel Slavery and Racism: A Reflection on the Dutch Experience", in Philomena Essed and Isabel Hoving (eds), Dutch Racism (Amsterdam, 20I4), pp. 3I-5I. For some exceptions focusing on the development of racialized representations in the metropole, see Allison Blakely, Blacks in the Dutch World: The Evolution of Racial Imagery in a Modern Society (Bloomington, IN, 1993); Angelie Sens, "Mensaap, heiden, slaaf". Nederlandse visies op de wereld rond I 800 (The Hague, 200I); and Dienke Hondius, Blackness in Western Europe: Racial Patterns of Paternalism and Exclusion (New Brunswick, NJ, 20I4). An East Indian perspective is provided in Ulbe Bosma and Remco Raben, Being "Dutch" in the Indies: A History of Creolisation and Empire, I500-1920 (Athens, OH, 2008), pp. $2 \mathrm{I}-25$.

9. This is, of course, true for the study of urban slavery more generally. Peter Wood talks about the "efforts to prohibit Negro socializing" in Carolina in the early eighteenth century, citing 
However, choosing the port city as a focal point in this research is not simply a matter of convenience. For understandable reasons, studies of social control in eighteenth-century Suriname have put most emphasis on plantation life. ${ }^{\circ}{ }^{\circ}$ In the context of the plantation, with its rigid social division between white masters and overseers and the black slaves, outnumbering whites by a ratio of more than ten to one, the almost complete overlap of social and racial distinction hardly appears as strange. The only real question for debate seems to be whether the growing racial exclusivity of plantation slavery was the result of latent prejudices that had always been present in European society, or whether race as a category was created from the outset as an ideological justification for an essentially economic system. ${ }^{\text {II }}$ The everyday functioning of social and racial distinctions was much less straightforward in port cities, where intermingling between social groups was extensive and hard to control, movement of people and goods was a given due to their commercial function and geographical location straddling sea and hinterlands, and society was much more socially diverse. ${ }^{\mathrm{I} 2}$ However, the notion of two separated worlds, the static and simple world of the plantation and the complex and dynamic world of the town, is based on an illusion. Constant movement between these worlds was the norm. This included the movement of many

I7I 2 legislation "against the numerous Negroes who entered Charlestown on Sunday and holidays in order - according to the whites - 'to drink, quarrel, fight, curse and swear, and profane the Sabbath, [...] resorting in great companies together, which may give them an opportunity of executing any wicked designs'”. Peter H. Wood, Black Majority: Negroes in Colonial South Carolina from I670 through the Stono Rebellion (New York and London, 1974), p. 272.

Iо. Gert Oostindie, Roosenburg en Mon Bijou. Twee Surinaamse plantages, 1720-1870 (Dordrecht, 1989); Alex van Stipriaan, Surinaams contrast. Roofbouw en overleven in een Caraïbische plantagekolonie 1750-I863 (Leiden, I993); and Ruud Beeldsnijder, "Om werk van jullie te hebben". Plantageslaven in Suriname, I730-1750 (Utrecht, I994).

I I. Among the vast literature on this question, see H. Hoetink, Slavery and Race Relations in the Americas: An Inquiry into their Nature and Nexus (New York, 1973); Alden T. Vaughan, "The Origins Debate: Slavery and Racism in Seventeenth-Century Virginia", in idem, Roots of American Racism: Essays on the Colonial Experience (Oxford and New York, 1995), pp. I36-174; Barbara Jeanne Fields, "Slavery, Race and Ideology in the United States of America”, New Left Review, I/ı8 I (1990), pp. 95-I 18; James H. Sweet, “The Iberian Roots of American Racist Thought”, The William and Mary Quarterly, 54:I (1997), pp. I43-I66; and Jorge L. Giovannetti, "Slavery, Racism and the Plantation in the Caribbean", Latin American and Caribbean Ethnic Studies, I:I (2006), pp. 5-36.

I 2. Douglas Catterall and Jodi Campbell (eds), Women in Port: Gendering Communities, Economies, and Social Networks in Atlantic Port Cities, I500-I800 (Leiden and Boston, MA, 20I2), and Jorge Cañizares-Esguerra, Matt D. Childs, and James Sidbury (eds), The Black Urban Atlantic in the Age of the Slave Trade (Philadelphia, PA, 2013). For what follows, see the powerful argument for mobility as a key factor in understanding slave societies presented by Julius S. Scott, The Common Wind. Afro-American Currents in the Age of the Hatian Revolution (London, 20I8). 
slaves, who, individually or in small groups, went to the port for chores, as rowers for the master or his goods, to perform hard labour on the fortress for the government as hired slaves, or to receive punishment. It also included the movement of slaves who had received temporary leave from the plantation to visit their families or sell goods in the market, and of those who had managed to escape and sought refuge in the town. It is exactly this perpetual movement between plantation and port - a crossing of boundaries in its own right - that made towns like Paramaribo focal points for the racialization of social control. Starting from a seemingly innocuous moment of contention, this article tries to capture this process of creating and enforcing boundaries in a sea of movement and intermingling.

\section{DISREPUTABLE DANCES, SWINGING BODIES}

What was the Paramaribo in which the widow Johanna Catharina Brouwer organized the "disreputable dance" (in Dutch: eclatant bal) for her daughter, and where did it fit into patterns of colonial sociability? In the decades after the capture of Suriname by a Zeeland fleet in I667, the Guyana settlement remained a fragile plantation colony built around the three villages Torarica, Jodensavanne, and Paramaribo nearest to the coast. The eighteenth century saw a rapid expansion of the colony's population and a steady growth in its economic importance to the Dutch Republic. Both reached their zenith in the first half of the I770s. The importance of Paramaribo grew accordingly, while the other two settlements remained villages. By I752, Suriname had a slave population of 37,835, of whom 2,264 lived in Paramaribo. In the same year, the white, mestizo, and free black population (excluding maroons and the indigenous) numbered 2,062, half of whom lived in Paramaribo. In addition, around 700 soldiers were stationed in Suriname, many of them garrisoned in Fort Zeelandia, which overlooked the Suriname River at the northern edge of Paramaribo. ${ }^{\mathrm{I}}$ Beyond Paramaribo, the plantation colony stretched out in two divergent strips along the Suriname and Commewijne Rivers. The middle of the eighteenth century formed a moment of rapid expansion and change, in which the value of coffee exports overtook that of sugar. The steep rise in the number of coffee plantations, from none in I7I 3 to around I40 by I745 and 295 around I770, lay behind the financial boom that made West Indian mortgages all the rage on Amsterdam's capital market. ${ }^{I 4}$ Dutch Atlantic trade steadily grew to

I3. Figures taken from Van Stipriaan, Surinaams contrast, pp. 3 I I and 3I4. See also Karwan Fatah-Black, "Paramaribo as Dutch and Atlantic Nodal Point, 1650-1795", in Oostindie and Roitman, Dutch Atlantic Connections, pp. 52-71.

I4. Van Stipriaan, Surinaams contrast, pp. 33-35. 

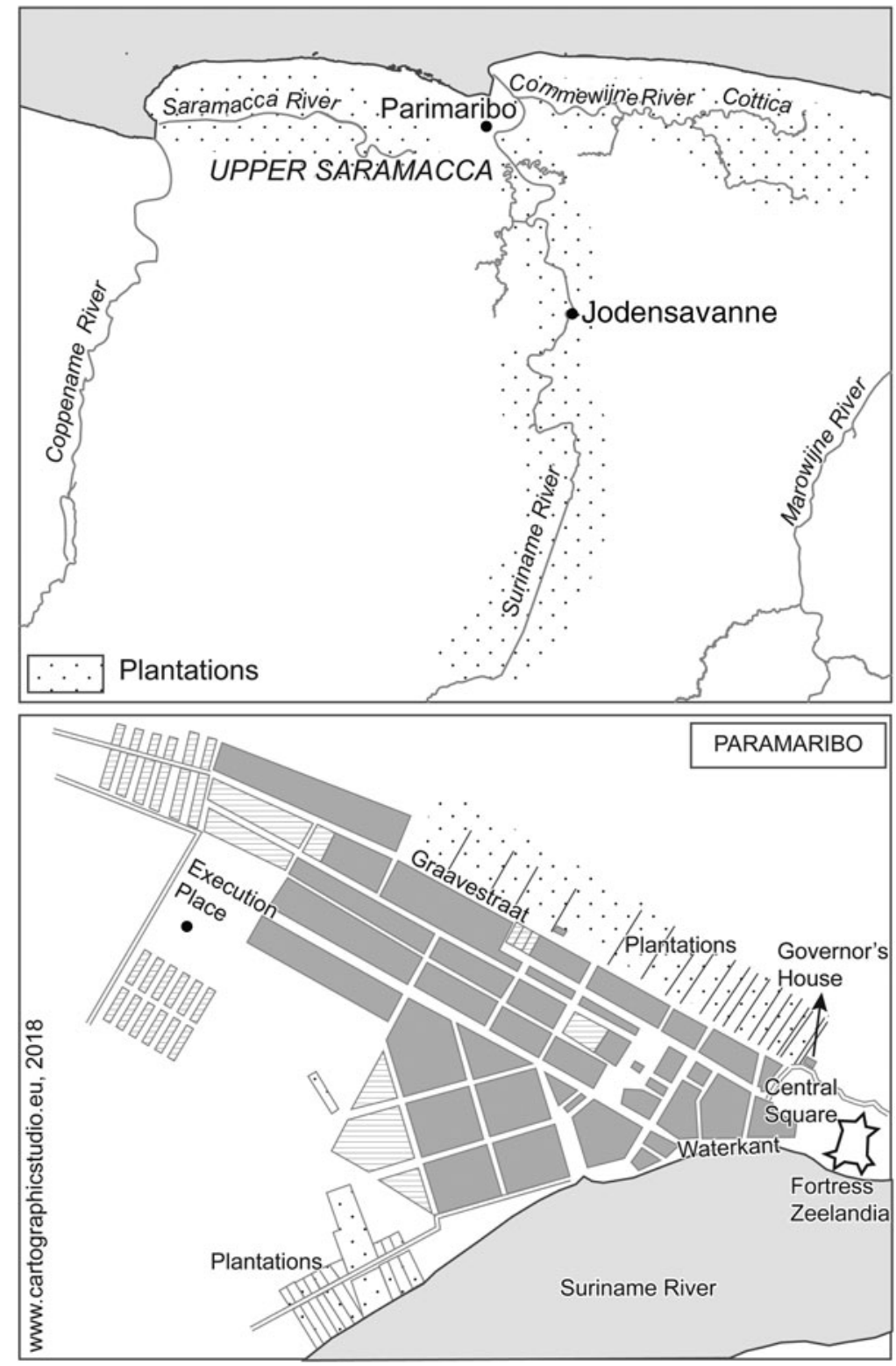

Figure 2. Top: map indicating the spread of plantations in mid-eighteenth-century Suriname. Bottom: map of Paramaribo including some of the main locations mentioned in this article. 
dimensions that rivalled the East India trade, while many other sectors of Dutch capitalism suffered a severe slump. ${ }^{\text {Is }}$

With the growth of the colony, the importance of Paramaribo as a node of urban production and a meeting place for transactions, for gathering news, and for participating in a more diverse social life increased. In this way, in the words of the Surinamese-Dutch scholar Rudolf van Lier, the town "became the centre around which all life in the colony revolved". ${ }^{16}$ Social and cultural life for the white planter class in Paramaribo included occasional balls of the type organized by the widow of Captain Brouwer, as well as visits to the theatre and the expensive coffee houses and taverns near the waterfront. ${ }^{17}$ When whites went out in the evening, it was not uncommon for them to bring several of their slaves to serve on them. ${ }^{18}$ For masters as well as for large numbers of slaves, though to a lesser extent for the latter owing to their more limited freedom of movement, Paramaribo became an important place of work, where they could obtain news and sometimes drink and socialize around the improvised bars and small shops (vettewariers) that were considered a continuous threat to social order by the colonial authorities. ${ }^{19}$ Fatah-Black details the street peddling done in the town by both slaves and poor whites, and the growth of markets where slaves sold the goods that they produced independently on the kostgronden (provisioning grounds) of the plantations. Markets "were mainly found in the less affluent parts of town, on the square near the church and on the waterfront" ${ }^{2 \circ}$ Of course, Paramaribo was itself an important location for slave labour. Many slaves in Paramaribo were employed as domestic slaves, but occupations also included traditional dock work and labour on the plantations on the outskirt of the town. Slaves carried out tasks for the plantation owners that required a temporary presence in the town, or worked there permanently as carpenters, butchers, or in other types of skilled labour. ${ }^{21}$ Their paths must frequently have crossed those of free blacks and mulattos who

15. Victor Enthoven, "An Assessment of Dutch Transatlantic Commerce, 1585-1817", in Johannes Postma and Victor Enthoven (eds), Riches from Atlantic Commerce: Dutch Transatlantic Trade and Shipping, I585-I 817 (Leiden and Boston, MA, 2003), pp. 385-445, 443. 16. Rudolf van Lier, Samenleving in een grensgebied. Een sociaal-historische studie van de maatschappij in Suriname (The Hague, 1949), p. 79.

17. A.F. Lammens, Bijdragen tot de kennis van de kolonie Suriname (Amsterdam, I982), p. 4I, notes the high prices in some of these taverns and coffee houses, which were within reach only of the quite well off.

18. Van Lier, Samenleving, p. 8I.

19. As can be gauged from the many regulations and cases of infringement surrounding official and improvised taverns and shops, gathered in NA-OAS, Archief Raad van Politie, I.05.10.02, no. 953, "Register van publicaties, notificaties en reglementen betreffende herbergiers, tappers, vettewariers, slachters, broodbakkers en pontevoerders over I717-1 824 ".

20. Fatah-Black, White Lies, p. I 43.

21. J.D. Kunitz, Surinam und seine Bewohner (Erfurt, I805), p. 72. 
carved out their livelihood in Paramaribo, indigenous hunters, white artisans, or sailors and soldiers who worked in town. Waged artisans, crewmen, and slaves often found themselves working side by side on a single project. ${ }^{22}$ Adriaan François Lammens, whose early nineteenth-century description of Suriname gives the most detailed picture of urban life in the colony, describes the scene of work and social and ethnic intermingling along the quay in a passage mixing admiration and class prejudice:

The view of the riverside, where forty to seventy, and sometimes more, seagoing vessels are anchored, is most agreeable: the loading and offloading of the ships, with the continuous coming and going of tent boats, ferries, carrying vessels, and corjaren; the strange sight of Indians, who come to visit Paramaribo; the general activity on the water. A daily, well-stocked fish market opposite the Jewish Broad Street produces an unpleasant sensation for the nostrils, which is not improved by the smells eluded by the working lower class; but one finds for this ample compensation in seeing the abundance of fish, crabs, fruit, and birds available at the market. ${ }^{23}$

Despite this lively portrait, the visible marks of repression and violence were never far off. Fort Zeelandia, which overlooked the governor's mansion, served as the place to which plantation owners had to bring slaves for punishment exceeding the maximum number of lashes they could administer privately. The square between the fortress and the mansion was the place of punishment for soldiers condemned to run the gauntlet. ${ }^{24}$ And a short walk along the Western outskirts of the town brought one to the funeral site reserved for nonwhites, as well as the place of execution containing "the remnants of the unlucky ones, who as a warning to others and as punishment for their evil deeds had to end their lives there". ${ }^{25}$ The close proximity between violence, work, and festivities, both in spatial and in symbolic terms, is well illustrated by a casual remark in the diary of the famed chronicler of the Surinamese Maroon Wars John Gabriel Stedman. On 9 March 1773, he noted:

I return to Paramaribo. N.B. During my absence 3 negroes were hang'd on the boat, and 2 whipt below the gallows. On the 8th [March], being the Prince of Orange his birthday, Colonel Fourgeoud gave a genteel supper and ball to the ladies and gentlemen, la sale de danse [in the] officers' guardroom. ${ }^{26}$

22. Fatah-Black lists cases of enslaved "carpenter-negroes” and waged shipwrights or ships' carpenters being employed to construct transport vessels: Karwan Fatah-Black, "Scheepsbouw en reparatie in achttiende-eeuws Suriname”, Tijdschrift voor Zeegeschiedenis, 36:2 (2017), pp. 6888 , with, for example, a case from January 1744 on p. 80.

23. Lammens, Bijdragen, p. 53 .

24. NA-OAS, Archief Gouvernementssecretarie, 1.05.10.01, no. 615, "Reglement voor de Militaire Troupen in de Colonie Suriname, $1778^{\prime \prime}$, p. 38.

25. Ibid., p. $5 \mathrm{I}$.

26. Stanbury Thompson (ed.), The Journal of John Gabriel Stedman 1744-1797, Soldier and Author: Including an Authentic Account of his Expedition to Surinam, in 1772 (London, 1962), p. I22. 
This, then, was the social and physical environment in which Johanna Catharina Brouwer organized her disreputable dance. ${ }^{27}$ According to Mauricius, when first announced, the plans for the party had already raised a murmur within polite society. The minister of the Reformed Church had ordered the sacristan to inquire with the widow whether she was aware that her ball would be taking place on the night before the Lord's Supper. In answer to these criticisms, Johanna Catharina replied that the ball would only be a children's party. ${ }^{28}$ Persisting against the wishes of the Reformed Church and high society's perceptions of good taste, she asked another widow, her aunt Wossink, for the use of her house. The request was far from innocent, for the house was strategically located between the commander's lodgings and the governor's mansion. It was an excellent place for a spectacle, for the same square also functioned as the parade ground of the garrison of Fort Zeelandia during festivities or official inspections. ${ }^{29}$ Around five in the afternoon of that fateful day, bystanders witnessed the arrival of the guests. These included, in Mauricius's words, "all the children of the Cabal" (meaning the youth from oppositional planter families)..$^{30}$ An hour later, to the sound of trumpets, the dance started. To add insult to injury, not long afterwards, one of the prominent guests started throwing fireworks and oranges towards the house of the commander and the governor's mansion, supported by "loud cries of slaves". ${ }^{3 \mathrm{I}}$

The exact timing of events is important to our understanding of the combination of digressions of the prevailing social order that followed. Mauricius is meticulous in establishing this timeline. According to him, at eight o'clock in the evening the clamour quietened down. Mauricius ascribed this to the fact that regulations prohibited slaves from being on the street without a lantern after this time of night. But shortly after nine, the trumpets started blowing again. This contained a second infringement on lawful restrictions of nightly activities, for among the musicians appeared to be a soldier, the army drummer Lorsius, who was required to be back in his barracks before nine on pain of running the gauntlet. ${ }^{32}$ The latter infringement of discipline provided the pretext for trying to shut the party down. But when Mauricius sent a non-commissioned officer, Hendrik Hop, to arrest Lorsius, the partygoers allowed the soldier to escape through the backdoor. When Hop inquired politely about the drummer, the lady of the house told him that

27. Report of the Dance of Widow Brouwer, 3 October 1750, du Plessis, Recueil, IV, p. 295.

28. Letter of Minister Yver to Governor Mauricius, 3 October 1750, ibid., p. 298.

29. Lammens, Bijdragen, p. $3 \mathrm{I}$.

30. Report of the Dance of Widow Brouwer, 3 October 1750, du Plessis, Recueil, IV, p. 296.

3 I. A fortnight later, the Suriname government council prohibited the throwing of fireworks in the colony. NA-OAS, Gouvernementssecretarie, I.05.10.01, no. 556, Kopie-notulen Hof van Politie en Criminele Justitie, 20 October 1750.

32. Report of the Dance of Widow Brouwer, 3 October 1750, du Plessis, Recueil, IV, p. 296. 


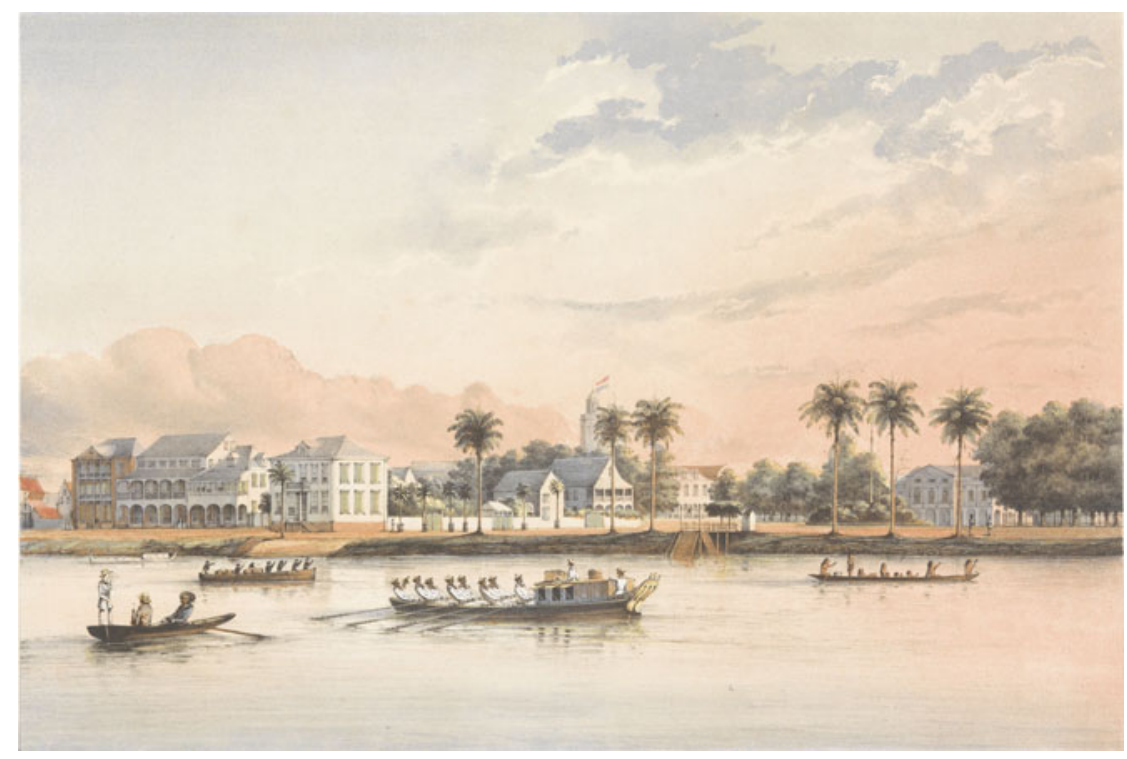

Figure 3. Nineteenth-century view of the government house and adjacent square of Paramaribo, Eduard van Heemskerck van Beest, after Gerard Voorduin, I860-I 862.

Rijksmuseum, Amsterdam.

Lorsius had already left by eight, and that "they had no need for soldiers in the house". After this, she shut the door in Hop's face. ${ }^{33}$

The enraged Mauricius sent the bailiff, but he, in turn, was intercepted by Johanna Catharina, who defiantly told him that "the Governor might be master in his house, but she was the master in hers". ${ }^{34}$ Meanwhile, new musicians had taken the place of the escaped soldier, the most notable of them a violinist referred to as "the young Crepy", a clerk at the Paramaribo secretariat and son of a prominent planter. One of the most ominous moments of the evening came when this young clerk interrupted the music to shout a mocking challenge to the authorities: "Tomorrow, all the citizens will eat Blakke Breddie". Employing a phrase in Sranan Tongo or "Negro English", as the English-based Creole language of Surinamese slaves was then commonly known, this supposedly meant as much as "tomorrow, all the citizens will be in jail". ${ }^{35}$ It was followed

33. Testimony of Landspassaat Hop, 4 October 1750 , ibid., p. 299.

34. Mastery of the house was also of course a crucial element of gendered power divisions. For comparison, see Susanah Shaw Romney, New Netherland Connections: Intimate Networks and Atlantic Ties in Seventeenth-Century America (Chapel Hill, NC, 20I4).

35. The modern name is Sranan Tongo. For the social significance of its use, see also Natalie Zemon Davis, "Creole Languages and their Uses: The Example of Colonial Suriname", Historical Research, 82:216 (2009), pp. 268-284. 
by "Hurrays" taken over by the children. To top it off, a trumpeter "had the temerity to blow on his trumpet, not orderly, but with the most infamous sound in the world, while wenches, children, and slaves loudly laughed and shouted". The shouts and "mocking trumpet blows" lasted until close to midnight, when Talbot, a member of the government council, came down from Fort Zeelandia and finally managed to disperse the crowd. ${ }^{36}$ In a separate series of comments on the events, added to the official report, Mauricius underlined the reason for his outrage:

To loudly shout under the Governor's windows at night that the citizens will be brought into the fortress in the morning and call out "Hurray!" for this, is such great and coarse rebellion as one can imagine. Just one step further, and the Citizens come and tear the house down. ${ }^{37}$

\section{THE CITIZENS WILL EAT BLAKKE BREDDIE}

The "children of the Cabal", who behaved in such a rowdy way right in front of the governor's house, in fact hailed from the higher echelons of Dutch Surinamese society. All the more powerful therefore was the symbolic inversion of social roles that was implied in the notion that the citizens were jailbound. Alleging that they had included "Negro English" in their mocking shouts, and to do so in reference to a fortress that also functioned as the central slave prison, further added to the scandalous nature of their utterance. Whether or not Mauricius really believed that the relatively minor infringements that caused him such irritation on the night of 3 October 1750 opened the road to all-out rebellion, his repeated insistence on this in his reports and letters suggests that his superiors in the Dutch Republic would at least recognize the subversive potential of the inversion. Conflicts over class belonging and social status played an important role in the political clashes between increasingly self-confident planters and the governor that divided the colonial state. Behind the anger expressed by each party over the lack of respect shown by the other loomed a greater fear: the existential angst that, while the colonists shouted, the slaves laughed.

36. Report of the Dance of Widow Brouwer, 3 October 1750, du Plessis, Recueil, IV, p. 296. As is clear from this and several other of the passages cited, gender and age play an important role in Mauricius's moral outrage. In this context, the pairing of children and slaves is highly significant, since in developing colonial law as well as in developing European conceptions of Africans in general both groups were frequently equated for being "dependent" and therefore unable to speak on their own behalf (onmondig). Hondius, Blackness in Western Europe, ch. 2.

37. "Remarks on the Report of the Dance", du Plessis, Recueil, IV, p. 297. The soldier Coenraad Noltmyer, one of the guards in front of Mauricius's house, gave a statement in which he repeated the phrase of Crepy as "tomorrow we shall eat black bread", without using Negro English. He declared he had heard a woman speaking similar words to the children who were present. "Verklaringe van den Canonier Coenraad Noltmyer", ibid., p. 300. 
Behind the conflicts that erupted in Suriname in the late I740s ultimately lay economic trends. In order to exploit the opportunities provided by the growing market for Atlantic products in Europe and burgeoning intercolonial trade and smuggling, planters worked to escape the restrictions imposed from above. In $173^{8}$, private West Indian traders forced the Dutch West India Company to relinquish its monopoly on the slave trade to Suriname. From the I740s onwards, a lively legal and illegal trade with the British North American colonies developed that would grow to enormous proportions by the end of the century. As a result, the planters could muster increasing economic power against the governor, who acted as a representative of mercantilist policies enforced by the Society of Suriname, and demanded to be treated with the respect that their wealth in their eyes bestowed upon them..$^{38}$ Economic success also fostered a more assertive attitude towards the motherland. In one of his first petitions to the States General, Samuel $\mathrm{du}$ Plessis, one of the most vocal members of the opposition within Suriname's government council, pointed out that "all inhabitants of these lands [i.e. the Dutch Republic], as well as the State itself, would be drawing considerable advantages and prosperity" as a result of the success of the colony. ${ }^{39}$ Suriname planters thus demanded acknowledgement of their role as important contributors to the wealth of the nation. However, colonial governors and their overseas directors tended to see the local elites as rabble and adventurers who had been able to outgrow their proper social sphere to live a life of debauchery in the colony..$^{\circ} \mathrm{A}$ particularly striking example of someone who, in the eyes of Governor Mauricius, had refused to observe the limits imposed by low provenance was Carl Gustav Dahlberg. For the course of events in October 1750, it is significant that, at the time of the scandalous ball, Dahlberg was eating the proverbial black bread. Even more significantly, he was Johanna Catharina Brouwer's lover.

Like many white soldiers and labourers who came to Suriname, Carl Gustav Dahlberg was of non-Dutch origin. In an angry rant in his journal, Mauricius alleged that the Swedish corporal had come to Suriname as part

38. Van der Meiden, Betwist bestuur; Fatah-Black, White Lies.

39. "Request, door Salomon du Plessis den 3 I July 1747 aan Haar Hoog Mog. gepresenteerd", Recueil, I, p. I.

40. The idea that in Suriname only knaves could make a fortune clearly comes to the fore in a play published in $\mathrm{I} 77 \mathrm{I}$, in which a plantation director echoes the common perception: "O Land vol list en schelmeryen, / Die Eerlyk is koomt in den noot, / Opregte deugt loopt hier om broot, / Genoopt van honger luydt te schryen." "“O Country of thievery and deceit, / Honest persons will fall into distress, / Sincere virtue will force you on the street, / To cry of hunger and beg for bread"]. Het Surinaamsche Leeven, toneelwyse verbeeld door Don Experientia (s.l., I77I), p. I 9. The perception, which also existed in other Atlantic empires, might have had a real social basis. The Atlantic provided many opportunities for captains and new merchants to establish themselves as large-scale traders. Robin Blackburn, The Making of New World Slavery: From the Baroque to the Modern, I492-I800 (London and New York, 2010), pp. 232-233. 
of a transport organized by zielverkopers. ${ }^{4 \mathrm{I}}$ This Dutch term refers to recruiters who used debt traps to force people into the army, the navy, or the service of the colonial companies. Being the victim of a zielverkoper thus automatically designated someone as poor. With some help, once in Suriname Dahlberg had apparently managed to climb to the rank of sublieutenant. It was enough of an advance in status for Dahlberg to become an attractive partner for the widow of a member of the government council and plantation owner Johanna Catharina Brouwer, a fact that in itself enraged Mauricius. In the latter's eyes, Dahlberg's engagement with the widow Brouwer, "one of the most impertinent and hellish shrews of the Cabal", only served him to build his fortune. ${ }^{42}$ Dahlberg would indeed marry Johanna Catharina Brouwer in March I75I, making him the owner of the plantations Brouwershaven and Carlsburg. In 1752, he quit military service and the couple settled in a house in the Heerenstraat in Paramaribo, for which they paid the very high annual rent of $\mathrm{I}, 000$ guilders. ${ }^{43}$ However, as long as he was in the military his love life put him directly at odds with his superiors. On I4 September 1750, his commander had put him under house arrest for unspecified "insolent words", for which he refused to apologise. ${ }^{44}$ Mauricius was quick to blame the wily ways of women for Dahlberg's behaviour, for "[a]ll his bravado is only to please his Infante". 45

Among the oppositionist planters, the arrest became instant proof of the tyrannical mode of operation of the governor and his cronies. In a session of the Military Court on 23 September, four against three council members voted for Dahlberg's release against Mauricius's advice, leading him to overrule the decision and refer the case to a later full session. ${ }^{46}$ In the week that followed, Dahlberg's house was the scene of daily solidarity visits by "the Ladies of the Cabal", who were received "with music". ${ }^{47}$ On 3 October, the arrestee even went as far as asking for a temporary release "because he would like to visit the dance" later that night. ${ }^{4}$ Not without reason, Mauricius was convinced that the prime reason behind the provocative gestures that took place at Johanna Catharina Brouwer's party was "that this Amante is piqued by the arrest of her beloved Dahlberg". ${ }^{49}$

4I. NA-OAS, Gouvernementssecretarie, I.05.10.0I, no. 5, "Journaal Mauricius 1748-1750", entry for I October 1750.

42. Ibid.

43. Oudschans Dentz, "Dahlberg”, p. 275.

44. NA-OAS, Gouvernementssecretarie, 1.05.10.01, no. 5, "Journaal Mauricius 1748-1750", entry for ${ }_{14}$ September 1750.

45. Ibid., I October 1750, significantly again linking supposed inferiority directly to childhood, although in this case the inferiority is based on gender rather than on status or race.

46. Ibid., 23 September 1750.

47. Ibid., I October 1750.

48. Ibid., 3 October 1750.

49. "Remarques", Recueil, IV, p. 297. 
The class anger apparent from Mauricius's comments on the relationship between Dahlberg and Brouwer was wholly in keeping with his general attitude to the oppositionist planters. When first confronted with a petition to the Dutch authorities signed by forty prominent whites, he had used similar slurs to describe his adversaries on the council. He referred to the planter du Plessis as "a raving upstart of a wig-makers apprentice", Taunay as an "old hunger-comrade", and the citizens' captain Amand Thomas as "a real Judas, who in his youth as a regimental barber-surgeon has escaped the gallows twice, now to make his fortune here". ${ }^{50}$ Whereas Mauricius claimed that the planters blurred social distinctions by rising from rags to riches, the planter oppositionists, in response, charged him with blurring social lines by degrading them in the eyes of ordinary soldiers and slaves. In I747, sixteen oppositionists, including Taunay, Thomas, and Brouwer (then still alive), complained about Mauricius's pardoning of two deserters who had been sentenced to death. After recalling that the freed soldiers had immediately deserted to a French privateer, they rhetorically asked: "Would it not be better to be a bit more rigorous towards the Soldiers, and a bit less towards Citizens?". ${ }^{I}$ In a further protest against the "tyrannical regime" of Mauricius, planters retold with even greater indignation the story of a government slave who in the eyes of the opposition had been unjustly released after attacking a free person. ${ }^{52}$ Again charging the governor with irresponsible laxity towards the upholding of social distinctions, they insisted that

an act of Connivance of that nature can only be of dangerous consequence, and must give the Negroes reason to set free their natural penchant towards evildoing even further. And so it is in this case [...] since aforementioned slave has later told [Sluyter] in public on the street: "Scoundrel, what good did your complaints do you? I will beat you with a stick, etc." ${ }_{3}$

The idea that the greatest danger of blurring class distinctions among the white population was to set free the forces of slave rebellion was widely shared on all sides of the conflict. During a meeting in Amsterdam, a supporter of Mauricius in the Society of Suriname emphasized that if the conflicts in the colony had been between Europeans alone, it would have been easy for the authorities to come to a settlement. The real threat from the

50. Van der Meiden, Betwist bestuur, p. Io3.

5. "Aan den Edele Agtb. Heer Salomon du Plessis tot Amsterdam, 6 February 1747", Recueil, I, p. 24 .

52. The free person was Frans Sluyter, who in May 1745 had walked along Paramaribo's Waterkant when five "negroes", including the slave of the government, had called him a "damned Mulatto" and thrown stones at him. "Poincten en Consideratien, dienende ter betoog van de nadeelige despotique en verre gaande geïnteresseerde Regeeringe van Mr. J.J. Mauricius, Gouverneur Generaal over de Colonie van Surinamen, Rivieren en Districten van dien, \&c. \&c. \&c.”, Ibid., p. 32.

53. Ibid. 
planter opposition arose from the fact that the forty social upstarts who put their signature under the protest could mobilize a force of ten to twelve thousand slaves. To make sure this never happened, it was imperative to prevent "turbulent spirits" from entering the Suriname planter class. The oppositionists again presented their own variant of this argument. Not their demands, but the tyrannical actions and lack of respect shown by Mauricius for his council would lead the slaves to lose the necessary reverence for their masters, threatening "a general massacre of all the Europeans". ${ }^{44}$ Thus, the invocation of largely imaginary class differences among the white planters became firmly attached to the question of the stability of the fundamental dividing line underlying colonial social order: that between African slaves and white masters.

\section{FORCES OF REPRESSION, SOURCES OF REBELLION}

The rulers' fears became all the more urgent since one of the key questions over which politics split in these years was how to deal with the rapid growth of actual slave resistance in the form of mass marronage and "slave conspiracies". For both parties, maintaining the slave-based social order was their primary concern. But whether this would be done best by increasing the planters' power on the plantation, or by strengthening the central institutions of state power based in Paramaribo became an issue that divided the colonial state up to the highest echelons. Fort Zeelandia, in the shadow of which the citizens danced and the slaves laughed on 3 October 1750 , was a focal point for these conflicts.

Practically from the start, colonial authorities had deemed the presence of a sufficient number of white labourers and supervisors on the plantation as the first line of defence against slave resistance. It is important to remind oneself that making white or European labour synonymous with supervision constituted an element of racialization, in the same way that equating the word "negro" with "slave" did.5 A string of new rules to solidify this division accompanied the transfer of control over the colony from Zeeland to the Society of Suriname in 1683 . On 24 January 1684 , the governor ordered owners to hand over lists that specified the number of white servants and the number of slaves on their plantations, prescribing that all plantations should have one white person as overseer for ten slaves. ${ }^{56}$ While frequently

54. Van der Meiden, Betwist bestuur, pp. 106-108.

55. Vincent Brown makes a similar observation in The Reaper's Garden: Death and Power in the World of Atlantic Slavery (Cambridge, MA, and London, 2008), pp. 22-23. See also Edmund S. Morgan, American Slavery, American Freedom (New York and London, 1975), pp. $338 \mathrm{ff}$; and Theodore W. Allen, The Invention of the White Race, 2 vols (London and New York, 20I2), II, pp. $239 \mathrm{ff}$.

56. J.T. de Smidt and T. van der Lee (eds), West Indisch plakaatboek. Plakaten, Ordonnantiën en andere wetten, nitgevaardigd in Suriname 1667-1816, 2 vols (Amsterdam, 1973), I, p. I37. 
repeated during the eighteenth century, the intended ratio of white servants to slaves proved to be wildly unrealistic. Lists handed over by the citizens' captains for 1740 mention the presence of 87 whites and 3,910 slaves on the plantations in the Thorarica region, and 79 whites and 1,872 slaves in Jodensavanne. These examples were representative for the entire period and for plantations throughout Suriname. ${ }^{57}$ Furthermore, while notoriously cruel towards the slaves, the white overseers especially were far from being a disciplined force. They mostly came from poor sections of the European population, under some of the worst conditions of employment available for colonial white labour. Table $\mathrm{I}$, based on a sample of almost 600 contracts of recruitment for eighteenth-century Suriname in the Amsterdam notarial archives, shows white overseers at the bottom of the hierarchy of white labour in terms of wages and length of obligatory contracts. Of the main groups of white labourers in the colony, with their wage of ninety guilders a year only soldiers earned less. ${ }^{5}$ Soldiers and sailors were sometimes recruited to serve as overseers, but their record of alcoholism and physical and sexual abuse was so infamous that an important manual for plantation managers from the late eighteenth century suggested that the chances of slave unrest would decrease by employing fewer of these guards. ${ }^{59}$ To strengthen the numbers and quality of their white personnel, plantation owners also tried to recruit skilled labourers such as carpenters, coopers, or barber-surgeons. However, as their average salaries and the frequent clauses for additional earnings indicate, the presence of these skilled labourers on the plantation was often only transitory, with many intending to set up shop for themselves as soon as the opportunity arose. ${ }^{60}$

Given the clear deficiencies of this small and divided white workforce as a barrier to slave rebellion, successive governors sought to create an apparatus of repression separate from the plantations. This included strengthening the army, fortresses, and guard posts, requisitioning citizens and slaves for patrol duties and hunts for maroons, and shifting some of the prerogatives in relation to punishing slaves from the individual planters to their collective representatives in Paramaribo. ${ }^{61}$ However, planters frequently opposed this buttressing of the colonial state. They insisted that instead of creating security it destabilized the self-contained order of the plantation. In April I744, the

57. NA-OAS, Archief Raad van Politie, I.I0.05.02, no. 580, "Opgaven van blanken, vrijen en slaven”, figures from reports by Dirk Guldensteeden, I740, David de Nassy, 1740.

58. Beeldsnijder, Plantageslaven, p. 42.

59. Anthony Blom, Verhandling over den landbouw, in de colonie Suriname, volgens eene negentien-jaarige ondervinding zamengesteld (Haarlem, i786), pp. 365-366.

60. Van Stipriaan, Surinaams contrast, pp. 284-285.

6r. On the development of central institutions for repression, see Jean Jacques Vrij, "Wapenvolk in een wingewest. De slavenkolonie Suriname, 1667-1799”, in Victor Enthoven, Henk den Heijer, and Han Jordaan (eds), Geweld in de West. Een militaire geschiedenis van de Nederlandse Atlantische wereld, I600-I800 (Leiden and Boston, MA, 2013), pp. 45-74. 
Table I. Employment contracts for West Indies in the Amsterdam notarial archives, eighteenth century.

\begin{tabular}{|c|c|c|c|c|c|c|}
\hline Job & Number & $\begin{array}{l}\text { Average duration } \\
\text { (months) }\end{array}$ & $\begin{array}{c}\text { Average wage } \\
\text { (guilders, first year) }\end{array}$ & $\begin{array}{c}\text { Average wage } \\
\text { (guilders, final year)* }\end{array}$ & $\begin{array}{l}\text { Contains provision } \\
\text { for extra earnings }\end{array}$ & $\begin{array}{c}\text { Receives advance } \\
\text { on wages }\end{array}$ \\
\hline $\begin{array}{l}\text { Director / } \\
\text { Administrator }\end{array}$ & 54 & 67 & 460 & $506(12)$ & $40(74 \%)$ & $1(2 \%)$ \\
\hline Barber-surgeon & 81 & 49 & 290 & $320(32)$ & $39(48 \%)$ & $34(42 \%)$ \\
\hline Clerk / writer** & 63 & 47 & 207 & $261(42)$ & $1(2 \%)$ & $14(22 \%)$ \\
\hline Carpenter & 150 & 46 & 349 & $372(45)$ & $21(14 \%)$ & $89(59 \%)$ \\
\hline $\begin{array}{l}\text { Manual labourers } \\
\text { (other) }\end{array}$ & 147 & 49 & 226 & $257(58)$ & $15(10 \%)$ & $81(55 \%)$ \\
\hline Overseers & 101 & 51 & 131 & $163(55)$ & $0(0 \%)$ & $46(46 \%)$ \\
\hline Total & 596 & 50 & 269 & $301(244)$ & $116(19 \%)$ & $265(44 \%)$ \\
\hline
\end{tabular}

Source: The sample of contracts is compiled from Simon Hart's inventory of Amsterdam notarial records, Stadsarchief Amsterdam (SA), Notariële Archieven, collectie S. Hart, nos 433-434.

* Between brackets: number of contracts that provided for a wage increase between the start and the end of the term.

** In practice, writers (schrijvers) often also acted as overseers. However, on average, contracting terms for those signified as writers were substantially better than for those hired as overseers, and closer to those hired as clerks. 
citizens' captain Pieter van Baerle from Cottica wrote a request defending masters in his precinct, who preferred to organize their own hunts for runaways, rather than employ government patrols. Van Baerle would later become fiscal council, the Paramaribo official responsible for punishing slaves brought to Fort Zeelandia. But as citizens' captain, he argued that the masters were right to hand out pardons on their own authority to recaptured runaways, and to refuse to bring slaves to the fortress. ${ }^{62}$ A year later, another planter defended evading the obligation to bring captured runaways to Paramaribo by lugubriously claiming that "nothing else but their heads" had returned from the hunt. ${ }^{63}$ The planters' allegation that the need to send slaves to Paramaribo for punishment could actually stimulate resistance finds some confirmation in a defiant saying used by slaves: "Tangi vo spansi boko mi bin si foto" - Thanks to the Spanish Bock I have seen the town. ${ }^{64}$ In addition, for many slaves, to be sent on a forest patrol provided the ultimate opportunity to join the maroons. ${ }^{65}$ Planters therefore often did not comply with a summons for patrol duty.

Plantation owners and directors raised similar complaints against the requirement to hire out slaves for building and maintaining the fortresses near the city. Like the obligation to supply slaves for patrols, in the eyes of the planters this weakened the workforce on the plantations. Furthermore, planters complained that they did not have enough white servants to guard their slaves on the way to and from Paramaribo, increasing rather than preventing possibilities of marronage. At the fortress itself, black supervisors frequently allowed slaves some time to go hunting and fishing to earn some money on the urban markets. ${ }^{66}$ Finally, Mauricius himself affirmed the complaint by the masters that working at the fortress brought slaves into contact with slaves from other regions, which tended to make them more rebellious and allowed them to learn new means of resistance, such as the use of poison. ${ }^{67}$ In part, the protests by the masters might have been a strategy in negotiating rent prices for their slaves. Before the arrival of Mauricius, they had managed to set a rate of twenty-four stuivers a day, twice the ordinary price for hiring a slave in Suriname. ${ }^{68}$ In comparison, in 1745 free day labourers at the fortress succeeded in obtaining a wage raise from six to twelve stuivers a day, and soldiers protested their

62. NA-OAS, Archief Raad van Politie, I.05.10.02, no. 286, "Ingekomen stukken, afgezonden door particulieren I740-I748", I 2 April I744.

63. Ibid., 3 I January 1745 .

64. Beeldsnijder, Plantageslaven, pp. I $32-133$. The Spanish Bock was a severe form of corporal punishment employed in Suriname, where a slave was bent over a contraption and whipped.

65. Wim Hoogbergen, "De binnenlandse oorlogen in Suriname in de achttiende eeuw", in Enthoven et al., Geweld in de West, pp. 147-182, г61.

66. Ibid., p. 79 .

67. Van der Meiden, Betwist bestuur, p. 95 .

68. Ibid. 
employment at this twelve-stuiver rate. ${ }^{69}$ The first conflict between the planters and Mauricius resulted from the latter's attempts to renegotiate the rate at which planters rented out slaves for work at the fortress.

The disputes over responsibilities in supplying the forces and building the infrastructure of colonial power were certainly not theoretical. The numerical weakness and divided nature of white society, combined with the geographical conditions of Suriname, provided the opportunity to build one of the more successful examples of resistance through mass marronage in Caribbean history. In total, Mauricius estimated the number of maroons living in independent communities surrounding the plantations or deeper inland at 3,000. By 1749, their combined strength had become so great that Mauricius was compelled to conclude a temporary peace with the maroons in Upper Saramacca. This peace was heavily contested by planters, who felt that any sign of compromise would encourage other slaves to follow the example of the "bush-negroes" ${ }^{70}$ In turn, Mauricius insisted that it was the arbitrariness of repression on the plantations combined with the lack of central forces to fight the maroons that put the colony in acute danger. Both sides found proof for their position in the uprising on the plantation of Armand Thomas that broke out on the evening of 21 February 1750. Only two days before, to suppress rumours caused by the peace treaty, the government council had ordered a stern warning to be read out on all the plantations that every slave who tried to join the maroons in Upper Saramacca would suffer beheading. Furthermore, the order emphasized that the peace treaty did not include any of the other maroon communities. Those "would be persecuted by fire and the sword with the utmost rigour" ${ }^{7 \mathrm{I}}$ However, it is an open question whether this announcement helped to suppress attempts at mass marooning or provided a final push.

The course of the rebellion on the plantation of Armand Thomas, which was the largest uprising on a plantation in the entire period in Suriname, and the brutal repression that followed, has been well described in the literature. ${ }^{72}$ On the evening of 2 I February, Thomas, whom we have already encountered as a citizens' captain and one of the leaders of the opposition to Mauricius, was beaten to death with a hammer by a group of slaves. His scribe, the only other white person on the plantation, soon followed his fate. The lifeless body of Thomas was severely beaten, and his whip was put in his mouth under shouts of "now eat it", signifying that Thomas's reign of terror on the plantation was one of the prime reasons

69. Beeldsnijder, Plantageslaven, p. 42.

70. Van der Meiden, Betwist bestuur, p. Io9.

7I. NA-OAS, Archief Gouvernementssecretarie, I.05.I0.0I, no. 556, "Kopie-notulen Hof van Politie en Criminele Justitie, 2 February 1750 - 27 January 175 I", entry I9 February 1750.

72. Van der Meiden, Betwist bestuur, pp. I Iо- I I , and Beeldsnijder, Plantageslaven, pp. 23 I234 . 
for the revolt. The rebels then took about thirty guns and tried to mobilize slaves on surrounding plantations. They were captured, and a long series of severe interrogations and torture started. The trial itself again revealed the divisions within the planter state. Mauricius blamed Thomas's arbitrary and violent rule on the plantation and his licentious sexual behaviour, including that towards an Indian slave called Eva, who, after the revolt, gave birth to Thomas's son, for causing the rebellion. As a result, he favoured a combination of exemplary death penalties for the leaders of the revolt and pardons for others. Members of his council insisted that the peace with the maroons in Upper Saramacca had inspired Thomas's slaves to rebel. They blamed Mauricius for undermining the authority of the planters on their own plantation. To restore their authority, they demanded the most brutal punishment for every slave involved. Showing the weakness of Mauricius's position in the council, they got their wish. At least thirty-four participants in the rebellion were sentenced to gruesome deaths. ${ }^{73}$

\section{MAINTAINING A CURFEW SOCIETY}

The uprising on the plantation of Armand Thomas preceded the central event in this article by eight months. While these were moments of contention of completely different magnitude and consequence, they are not entirely unconnected. In the wake of the partial peace with the Saramacca maroons and the uprising on Thomas's plantation, fears of conspiracies were running wild. These were not confined to slaves on the plantations nearer to the maroon villages; they were raised, too, against slaves who lived and worked in and around Paramaribo, as well as against members of the free population suspected of collaborating with them.

A particularly interesting case that highlights the importance of slave mobility and the diversity of contacts between free and unfree persons was the charge brought against Askaan and April. Both were owned by the "separated wife of Johan van Hertsberg", Willemina Schroder. Their captors found six guns with April belonging partly to him and partly to Askaan, and the prosecutor stated that these were intended for "fighting against the whites, or making attempts at rebellion". ${ }^{74}$ Even under torture, the two captives maintained that they planned to use the guns only for hunting. ${ }^{75}$

73. The interrogations and sentences of those involved in the uprising on Thomas's plantation fill several hundred pages in NA-OAS, Archief Raad van Politie, 1.05.10.02, no. 80I, "Processtukken betreffende criminele zaken 1750".

74. Ibid., $268 \mathrm{r}^{\circ}$.

75. An astoundingly rich description of criminal justice in Suriname, white practices of torture and disfiguring, and sources of the African slaves' resilience under duress can be found in Natalie Zemon Davis, “Judges, Masters, Diviners: Slaves' Experience of Criminal Justice in Colonial Suriname", Law and History Review, 29:4 (20I I), pp. 925-984. 
However, they did reveal an interesting network of contacts through which they had acquired these arms. Askaan said that April had bought one gun from Sockelaet (or Chocolate), who was a slave at the almshouse, received two from the free black man Adoe, bought or hired one other for eight shillings, and had bought two older guns from the "Jew negro" Agouba or Prins, who lived on the Waterkant. The "negress Europa, who used to belong to the ensign Meijer", had supplied a calabash of gunpowder. In addition, an earlier interrogation had led to the conclusion that gunpowder and bullets had been bought from an "Indian". During his trial, his interrogators asked Askaan whether he was not aware "that one white person has enough courage to take aim at a hundred slaves". ${ }^{76}$ However, when push came to shove his persecutors preferred not to take the risk. Despite his insistence under torture that he had not planned to use the guns against his masters, on 5 June 1750 Askaan was sentenced "to the cord", his head to be put on a stake, and his "cadaver to be burnt to ashes". ${ }^{77}$ Similar attitudes were shown in a simple case of marronage that occurred around that time. Quater Cheureua from the plantation of Jacques de Crepij near Paramaribo was brought to Fort Zeelandia accused of wanting to join a village of runaways. To the "very pernicious design to desert", the authorities added the charge of conspiracy. Quater was sentenced to be brought to the execution terrain, where he was bound on a cross, his bones broken "from the bottom upwards", and beheaded. His lifeless body was then subjected to the same ritual disfiguring as Askaan's. ${ }^{78}$

Next to the mounting slave resistance, the internal division of the white community and the apparent weakness of the apparatus of repression, authorities considered the mobility of slaves and the poor, whether black, mestizo, or white, to be one of the greatest potential dangers to social order. A crucial tool for the regulation of colonial society was an intricate web of curfews and passports restricting the movement of different groups among the lower classes. The breaking of such curfews by slaves who remained on the square before the governor's house after sunset, and by a soldier who did not return to his barracks after nine in the evening, played an important role in Mauricius's description of the "disreputable dance" of early October 1750. This was a direct reflection of the importance attached to upholding curfews in Suriname everyday life. Of course, the idea that controlling the movement of working people and the poor was imperative to maintaining order was nothing new. Especially in the dire persecution of beggars and the restrictions imposed on itinerant day labourers not attached

76. NA-OAS, Archief Raad van Politie, I.05.10.02, no. 801, "Processtukken betreffende criminele zaken $1750^{\prime \prime}, 27$ Ivs $^{\circ}$.

77. Ibid., 2681 $\mathrm{r}^{\circ}-27 \mathrm{IVs}^{\circ}$, and Recueil, IV, pp. 290-29I.

78. NA-OAS, Archief Raad van Politie, I.05.10.02, no. 801, "Processtukken betreffende criminele zaken $1750^{\circ}, 230 \mathrm{r}^{\circ}-230 \mathrm{vs} \mathrm{s}^{\circ}$ and $243 \mathrm{r}^{\circ}$. 
to a master or guild, European states and town governments had long experience in regulating who could be where to do what, and under what conditions. ${ }^{79}$ Frequently, such practices arose simultaneously from fear of rebellion and more immediate concerns about property and theft. Similar motivations existed in the imposition of a regime of curfews in colonial contexts. ${ }^{8 \circ}$ However, the more limited reach of authority, the semi-militarized conditions and legal structures under which the lower classes were forced to operate, and the presence of large indigenous and enslaved populations greatly amplified their use.

Already in 1669 and 1670 , just a few years after the Dutch takeover of Suriname, ordinances were published admonishing plantation owners to control the movement of their slaves more strictly by allowing them to move off the plantations only with passports, within set times, and for clearly delineated purposes. ${ }^{81}$ Attempts to limit the unsupervised movement of slaves conspicuously mixed with concerns about tying wage labourers to a single place of employment. Significantly, these first regulations already entailed divisions between black and white labourers that went beyond the simple substitution of the word negro for slave. A separate clause in the March I670 labour regulation addressed the status of manumitted Africans, saying:

That all negros that have received their liberty from their masters, will be obligated to hire themselves out to one master or another, on penalty of being severely whipped every time of being found without employment or being in someone's service. ${ }^{82}$

Fears that uncontrolled movement or a life outside employment for free and unfree blacks would create openings for smuggling and the sale of stolen goods provided the initial thrust for such racialized legislation. A I679 ordinance prohibited "any boats without white people on board" from travelling on rivers or creeks without express permission of plantation owners, alleging that "several boats with negroes [...] go up and down the river to ravage here

79. John Torpey, The Invention of the Passport: Surveillance, Citizenship and the State (Cambridge, 2000), pp. I8-19. However, Torpey's account of the pre-history of the passport also reveals an important difference. Focusing on local regulations, he states: "Until the ultimate triumph of capitalism and the nation-state in nineteenth-century Europe [...] controls on movement remained predominantly an 'internal' matter". In a colonial context where the state often started as an urban settlement with its surroundings, controls on movement were from inception a prerogative of the central authorities.

80. For example, see the ${ }_{1} 6_{3} 8$ regulations prohibiting sailors from being on shore at night, and ordering work bosses to strictly control the time at which their labourers in New Amsterdam arrived and left, in E.B. O'Callaghan (ed.), Laws and Ordinances of New Netherland, 1638 I674 (Albany, NY, I868), pp. Io-I 2.

81. De Smidt and Van der Lee, West Indisch plakaatboek, I, Ordinance of I 3 June I 669 and Ordinance of I2 March I670, pp. 44-45 and 57 respectively.

82. Ibid., p. 57. 
and there". If the black passengers of such a boat without whites failed to show their passes at first call, their vessel should be shot at "as if at public enemies, because for the service of the land and the preservation of the colony, they should be viewed as such". ${ }^{83}$ Another prohibition to trade goods with slaves in June 1684 and a similar one against trading with slaves or soldiers in May the next year followed this. ${ }^{8}$ Perhaps the most striking rule, effectively introducing an early form of racial profiling, allowed sentries to shoot on sight any black person on the streets later than half an hour after sundown "as if they were runaways". As a justification, the regulation explained that this was necessary "because at night one cannot tell the good from the bad negroes, since one cannot tell the difference from their cloths". 85

In the heated atmosphere of the late I740s, maintaining slave curfews became a particularly important element in enforcing public order. To assist in this task, the government council decided on 5 September 1747 to install a clock in the tower of Fort Zeelandia. ${ }^{86}$ Even a full century later, a traveller in Suriname noticed that every day at eight o'clock in the evening a cannon would be fired from the fortress, which contained the only public clock in Paramaribo, to mark the moment when slaves should be indoors. ${ }^{87}$ In the summer of 1749, new rules followed prescribing that slaves could be on the streets of Paramaribo at night only if carrying a lantern, and that the citizens' guard should start making its rounds at seven in the evening. ${ }^{88}$ However, given the prevailing tensions among white citizens the mode of operation of these citizens' guards created its own problems. On 4 December 1749, the government council discussed at length the disorders created by citizens, who randomly opened fire on slaves who merely sat on the pavement outside their masters' houses, or were walking the streets in the presence of their masters "so that shots of hail flew around and through the company". Apparently, several of the inhabitants of Paramaribo had already been shot in such altercations. When the NCO Bulke, who was responsible for opening fire, was questioned by his lieutenant, he had answered: "We want to shoot at slaves, and if not, you should dissolve the citizens' guard". ${ }^{89}$ Based on this testimony, the council considered only the possibility that shootings at night were a form of protest against guard

83. Ibid., p. 102.

84. Ibid., pp. I 43 and I55-156.

85. Ibid., p. I44.

86. NA-OAS, Archief Raad van Politie, I.05.10.02, no. 165, "Register", 5 September 1747.

87. Gaspard Philippe Charles van Breugel, Dagverhaal van eene reis naar Paramaribo en verdere omstreken in de Kolonie Suriname (Amsterdam, 1842), pp. $23-25$.

88. NA-OAS, Archief Raad van Politie, I.05.10.02, no. I65, "Register", 4 August I749.

89. NA-OAS, Archief Raad van Politie, I.05.I0.02, no. 43, "Minuut notulen I749", 4 December I749. 
duty. However, Bulke's answer also suggests how easily policing the street could slip into vigilante actions against the slaves.

A safer, less contentious way of maintaining order on the street was to try to close down venues for unguarded activity after hours, especially where such venues provided a space for interaction between slaves and free whites and blacks. Many rules and regulations were aimed at enforcing separation, especially in the context of travelling back and forth to Paramaribo. Among the most notorious were the draconian mutilations introduced as punishment for black and Indian slaves found drinking and playing games with white people in taverns (I698), and punishment by death for any "negro" having sexual relations with a white woman (I7I I)..${ }^{\circ}$ Curfews on soldiers and sailors also helped to limit interaction. This included the rule that, after the evening call, soldiers should remain confined in their barracks on pain of running the gauntlet. ${ }^{9 \mathrm{I}}$ However, in such attempts the authorities were up against what was perhaps the most powerful enemy of the curfew and of social segregation in general in the port city: the underground bar. In early February 1750, the court in Paramaribo sentenced the German immigrant Christiaan Crewitz for inviting "several Negroes into his house, where sitting at his Table, he served them beer and soup", as well as selling alcohol to several others. ${ }^{92}$ One of the most interesting elements of the case is that Crewitz, who declared that before opening a small bar he had made a living by "catching tortoises with the Indians in the river Marrewyne", repeatedly professed that he did not believe he had done anything wrong by serving drinks to black men. ${ }^{93}$ Crewitz was condemned to pay a fine of 500 guilders, the equivalent of between two and four years' salary for an unskilled worker in Suriname, and was banished from the colony for life. ${ }^{94}$

The trigger-happy NCO Bulke and Crewitz can be seen as presenting opposite ends of white society in Paramaribo. However, these opposites might not always have been as far apart as they seem. Their everyday context brought lower-class whites into continuous contact with the enslaved, sometimes as overseers, sometimes as colleagues, buyers and sellers, gamblers or drunks. This could be the basis for reflections on shared miseries, as well as for the exploitation of their whiteness as a protective shield against the

90. De Smidt and Van der Lee, West Indisch plakaatboek, I, pp. 2 I 9-22 I and 277. White women who were found in such relationships would be severely whipped, for the "great scandal they caused the entire colony".

91. NA-OAS, Archief Gouvernementssecretarie, 1.05.10.01, no. 615, "Reglement voor de Militaire Troupen in de Colonie Suriname, 1778”, p. 63.

92. NA-OAS, Archief Raad van Politie, I.05.10.02, no. 800, "Processtukken betreffende criminele zaken, $1750^{\circ}, 3 \mathrm{r}^{\circ}-3 \mathrm{vs}^{\circ}$.

93. Ibid., $5 \mathrm{r}^{\circ}-5 \mathrm{vs}^{\circ}, 6 \mathrm{r}^{\circ}-6 \mathrm{vs}^{\circ}$, and $\mathrm{I} 3 \mathrm{r}^{\circ}-\mathrm{I} 3 \mathrm{vs}^{\circ}$.

94. Ibid., $3 \mathrm{vs}^{\mathrm{o}}$. 
masters. The two attitudes could even exist side by side. John Gabriel Stedman described the working conditions of many common sailors:

In every part of the colony they are no better treated, but, like horses, they must (having unloaded the vessels) drag the commodities to the distant storehouses, being bathed in sweat, and bullied, with bad language, sometimes with blows; [...] The planters even employ those men to paint their houses, clean their sash windows, and do numberless other menial services, for which a seaman was never intended. All this is done to save the work of their negroes, while by this usage thousands are swept to the grave, who in the line of their profession alone might have lived for many years; [...] I have heard a sailor fervently wish he had been born a negro, and beg to be employed amongst them in cultivating a coffee plantation. ${ }^{95}$

As an answer to real or perceived social degradation, many embraced cruel displays of racial superiority, as did the sailor who, in passing, "broke the head of a negro with a bludgeon, for not having saluted him with his hat". ${ }^{96}$ In this case, as in Bulke's, racist attitudes among the white population became a powerful instrument for maintaining the curfew society.

\section{COLONIAL ROUGH MUSIC}

The previous sections have examined how the physical surroundings, the context of political tension within the planter class and slave resistance, and the importance of curfews for the maintenance of racialized social order all provide elements for understanding the contentious nature of Johanna Catharina Brouwer's dance. This final brief section will look at the significance of the most carnivalesque aspect of the confrontation that took place on the night of 3 October 1750: rough music, both in its literal and its symbolic sense represented by the trumpeter playing "the most infamous sound in the world, while wenches, children, and slaves loudly laughed and shouted". Music and dance played a crucial role in Suriname slave life. It provided not only one of the rare instances for truly independent social interaction, but also a vehicle for passing on secret messages undetectable to the ear of the masters, concealed in song, rhythm, or dance movements. ${ }^{97}$ From the other side, a vehement dislike of African song and dance was one of the important cultural markers of the distance between

95. John Gabriel Stedman, Narrative of a Five Years' Expedition against the Revolted Negroes of Surinam (Amherst, MA, 1972), p. 58. See also Karwan Fatah-Black, "Slaves and Sailors on Suriname's Rivers", Itinerario, 36:3 (2012), pp. 6I-82.

96. Stedman, Narrative, p. 58.

97. Alex van Stipriaan, "Muzikale creolisering. De ontwikkeling van Afro-Surinaamse muziek tijdens de slavernij”, OSO. Tijdschrift voor Surinaamse Taalkunde, Letterkunde, Cultuur en Geschiedenis, I9: (2000), pp. 8-37. Cf. Frantz Fanon, Les damnés de la terre (Paris, 2002 [1961]), pp. 57-58. 
civilized (white) society and the world of the slaves. In his nineteenthcentury travelogue, Gaspard van Breugel attested to his understanding of the importance of this marker by inserting the following description of a banja, a slave dance:

To unite their voices with their instruments, one sees the so-called musicians seated on the ground in a row; hitting their also so-called instruments, twisting their bodies and nodding their heads, while drawing faces with which one could immediately scare the naughtiest children to bed [...] Behind them stands a crowd that shouts, more than sings, in such a way that one needs a bale of cotton to plug one's ears not to hear that beautiful music..$^{8}$

Well aware of the power of music as an instrument to mock the white masters, or worse, colonial authorities throughout the period of slavery waged an uphill battle to prevent the slaves from singing, playing the drums, and dancing. Funerals in particular became moments of contention..$^{99}$ On 6 February I750, the government council discussed the "frequent assembly of slaves [in Paramaribo - PB] for funerals". The immediate cause of this discussion was the funeral of one of the slaves of S. Clijn. A large crowd had gathered in front of his house, "making much noise and rumour, creating confusion and murmurs". ${ }^{100}$ The council reconvened to discuss concrete measures on 26 February, a few days after the news of the uprising on the plantation of Armand Thomas had reached Paramaribo. In this session, the council decided to allow masters who owned houses or gardens outside the city to bury their slaves there instead of in the town's slave graveyard. For slave funerals that did take place in Paramaribo, the bailiff was ordered to make sure that no "noise" accompanied the ceremony. Masters who allowed any form of baljaaren (dancing) during a funeral would be fined 500 guilders. Slaves arrested during a funeral for contravening this order would receive the Spanish Bock. ${ }^{\mathrm{I}}$ I

Was Mauricius's remark on the quality of the trumpet playing at the party of Johanna Catharina Brouwer an allusion to yet another barrier of social order and racial distinction being crossed? This will have to remain a speculation. However, it is interesting to note that almost all reports on neighbourhood brawls in Suriname in this period mention noise and loud music as major affronts to public decency. On 20 November 1748, Pieter Brouwer returned from his plantation to his house in Paramaribo to nurse his sick wife. The next evening, at around nine-thirty, a loud party began in the house of his neighbour Dirk Brendt. Musicians played the violin and blew

98. Van Breugel, Dagverhaal, p. 63.

99. As they did elsewhere, as is shown by Brown, Reaper's Garden, ch. 2.

I00. NA-OAS, Archief Gouvernementssecretarie, I.05.I0.01, no. 556, "Kopie-notulen Hof van Politie en Criminele Justitie, 2 February 1750 - 27 January I75 I”, entry 6 February 1750.

Iог. Ibid., entry 26 February 1750. 
horns, "accompanied by continuous shouts of Hurrays and other noise". Brouwer alleges that Brendt was too drunk to pay a visit to his house and complain, so that the party continued until half an hour before midnight. However, the next morning the party resumed. What most upset Brouwer was that, "probably to increase the noise", to the horns was now added "the sound of a drum, again accompanied by continuous shouts of Hurray, at which hundreds of black boys gathered in front of the door". This was the final straw that led Brouwer to complain about his neighbour's behaviour, but Brendt did not take this well. Instead, he came to Brouwer's door to shout: "Canaille, did you have the heart to complain about me to the Fiscal, I will goddamned tear you to pieces." Fighting ensued, and ended only when soldiers came to take Brendt to the fortress. ${ }^{102}$ In this 1748 case, the actual overstepping of the proper time for celebration and dancing, playing noisy music, and involving slaves in a public spectacle figured in ways very similar to the descriptions encountered in Mauricius's October I750 complaint to underline a breakdown in public order.

References to slave dances or baljaaren could also be employed to hint at even greater digressions, connected to both gendered and racialized distinctions. This is revealed by an explosive brawl that took place just a few years earlier in the Gravestraat or Soldiers' Street, which ran between the central square and the gardens on the outskirts of Paramaribo. In the late afternoon of 22 October I745, violence erupted between Moses Levy Ximenes and David and Rachel Moateb, a mulatto. The root of the fight was that earlier, David and Rachel had visited Moses's father to complain about the noise emanating from his house. The old Ximenes had had a loud argument with one of his enslaved female servants. According to Rachel, Moses' father had responded to the complaint by "calling her husband a mulatto". Despite the fact that she herself was of mixed descent, she took this as a grave insult since her husband "was a legitimate white man" like Moses's father. ${ }^{103}$ According to Moses, the real insult had been David and Rachel's interference with a domestic affair, since it was his father's right "to chastise [kastijden] his negroes with words". ${ }^{104}$ Between the two parties, testimonies differed over the question of who at this point was the first to resort to physical violence. However, one other small difference between the statements given in this case

102. NA-OAS, Archief Raad van Politie, I.05.10.02, no. 920, "Processtukken aangaande criminele en politieke zaken", I747-1749, Testimony Pieter Brouwer, 25 November 1748.

103. NA-OAS, Archief Raad van Politie, I.05.10.02, no. 800, "Processtukken betreffende criminele zaken, 1750 ", $103 \mathrm{r}^{\circ}$, testimony Rachel, mulatto. The question of the complex in-between status of mulattoes in Surinamese society is too complicated to go into here. However, the fact that Rachel saw the employment of the word "mulatto" for someone who was "legitimately white" as a grave insult is itself proof of the extent to which social difference had become racialized.

104. NA-OAS, Archief Raad van Politie, I.05.10.02, no. 800, "Processtukken betreffende criminele zaken, $1750^{\circ}$, I $23 \mathrm{vs}^{\circ}$. 
matters more for the current purpose. One of the neighbours gave testimony to support Moses's plea. In this statement, rather than talking about his father's chastising of his slaves, Moses was presented as saying: "What do you have to do with the quarrel [ruzie] of my father, as he danced [baljaer$d e n]$ with his slaves." ${ }^{\circ}$ ' The word baljaeren in this context is so strange that one cannot help suspecting an unspoken meaning, pertaining to violence, sex, or both. In any case, it helps to underline a point that is crucial for understanding what happened on the night of 3 October 1750 . When involving masters and slaves, a dance was never just a dance.

\section{CONCLUSIONS}

Starting from an incident in colonial Paramaribo in the autumn of 1750 in which, according to the Dutch governor Mauricius, many of the proper barriers separating rich and poor, men and women, adults and children, white citizens and black slaves were crossed, this article has traced the complexities of everyday social control in colonial Suriname. The rowdy ball for the birthday of Johanna Catharina Brouwer's daughter, which drew the governor's ire, can easily be understood as a minor skirmish in the long-lasting conflict between the increasingly confident colonial planter class in Suriname and the local representatives of Dutch company rule. In the middle of the eighteenth century, such conflicts occurred throughout the Atlantic world as a result of the rapid rise of a Creole colonial elite, which self-confidently asserted its role in expanding capitalist networks across European empires. However, as so often in the history of popular rebellion, divisions within the ruling class also brought to the fore deeper fissures between the political and economic elites on the one hand and the lower classes on the other. Through the prism of the different transgressions mentioned by Mauricius in his report and letters about the "disreputable dance", we can observe essential characteristics of repression and rebellion in mid-eighteenth-century Suriname. In particular, it can be shown how instruments of social segregation with a long pedigree - enforcing distinctions of class and status, invoking taboos to limit the free interaction between men and women and adults and children, restricting the movement of labourers and the poor through passports and curfews - intersected with the harsh racialized separations of an eighteenth-century Atlantic slave society.

Much of the literature on the relationship between slavery and race focuses on the plantation as race-making institution and the planter class as the immediate progenitors of racial capitalism. Studies of urban slavery on the other hand have emphasized the greater scope for social contact between

I05. Ibid., I $25 \mathrm{r}^{\mathrm{o}}$, testimony Schröder. 
blacks, mestizos, and whites of various social status in the bustling port cities of the Atlantic. This article has attempted to understand practices of racialization and control in the port city of Paramaribo, not by contrasting the city with its plantation environment but by underlining the connections between the two social settings that together shaped colonial geography. Continuous movement between plantation and port, including the unsupervised movement of slaves, was a crucial aspect of the political economy and the cultural life of a society like Suriname. The article has focused on everyday activities in Paramaribo (dancing, working, drinking, arguing) that reveal the extent of contact between slaves and non-slaves. The imposition of racialized forms of repression that set one group against the other, frequently understood primarily as a means to justify the apparent stasis of the plantation system with its rigid internal divisions, in practice functioned precisely to fight the pernicious effects of mobility in mixed social contexts. In the process, plantation owners and the state that they at least in part controlled could sometimes find themselves at loggerheads, but, ultimately, they found themselves united in their primordial fear - that of slave rebellion.

One charge that could be made against this article is that the impact of mobility has not been researched through systematic quantification. Instead, it has illuminated key aspects of social relations in colonial Paramaribo through discursive practices at a moment of widespread contention. The new social historians of the I 970 s employed this method to reveal the importance of rituals, culture, and perceptions of justice at a time when their colleagues were mostly concerned with hard material factors. This article has in a way tried to retrace their steps. Starting from cultural practices and real and imagined distinctions of status, gender, age, and race surrounding an apparently innocuous birthday party, it has sought a way back to the brutal realities of colonial control in which these imaginings obtained their violent urgency. 